\title{
The Psychology of Forensic Evidence
}

Citation for published version (APA):

Sagana, A., \& Sauerland, M. (2020). The Psychology of Forensic Evidence. Zeitschrift für Psychologie, 228(3), 145-148. https://doi.org/10.1027/2151-2604/a000418

Document status and date:

Published: 01/07/2020

DOI:

10.1027/2151-2604/a000418

Document Version:

Publisher's PDF, also known as Version of record

Document license:

Taverne

Please check the document version of this publication:

- A submitted manuscript is the version of the article upon submission and before peer-review. There can be important differences between the submitted version and the official published version of record.

People interested in the research are advised to contact the author for the final version of the publication, or visit the DOI to the publisher's website.

- The final author version and the galley proof are versions of the publication after peer review.

- The final published version features the final layout of the paper including the volume, issue and page numbers.

Link to publication

\footnotetext{
General rights rights.

- You may freely distribute the URL identifying the publication in the public portal. please follow below link for the End User Agreement:

www.umlib.nl/taverne-license

Take down policy

If you believe that this document breaches copyright please contact us at:

repository@maastrichtuniversity.nl

providing details and we will investigate your claim.
}

Copyright and moral rights for the publications made accessible in the public portal are retained by the authors and/or other copyright owners and it is a condition of accessing publications that users recognise and abide by the legal requirements associated with these

- Users may download and print one copy of any publication from the public portal for the purpose of private study or research.

- You may not further distribute the material or use it for any profit-making activity or commercial gain

If the publication is distributed under the terms of Article $25 \mathrm{fa}$ of the Dutch Copyright Act, indicated by the "Taverne" license above, 


\title{
Editorial
}

\section{The Psychology of Forensic Evidence}

\author{
Anna Sagana and Melanie Sauerland \\ Faculty of Psychology and Neuroscience, Maastricht University, The Netherlands
}

The use of forensic evidence in criminal cases is certainly nothing new. Witness evidence and confessions are as old as the legal system itself and the earliest application of forensic-like techniques dates back to the ancient Greek and Roman societies (see work of Roman jurist Quintilian, Declamationes Maiores, 1.11-12; as cited by Killgrove, 2018). The need for forensic evidence is self-evident. Forensic evidence helps reconstruct the historical event, which is the criminal act (Kiely, 2005). However, this reconstruction offers only an approximation of the true event. The accuracy of this approximation depends on the accuracy and reliability of the employed techniques and, ultimately, on our understanding of the world.

Unfortunately, it is only lately that researchers have started to investigate the (corruptive) influences of forensic evidence and forensic science in criminal and civil investigations. We now begin to realise that the collection and interpretation of forensic evidence are susceptible to contextual influences and biases (Kassin, Dror, \& Kukucka, 2013). Contextual influences are extraneous factors that are irrelevant to the decision at hand because they do not change the essence of the decision problem (Dror \& Rosenthal, 2008) and do not improve decisional accuracy. Such extraneous factors include the context, emotional states, and expectations. Bias occurs when the observable result of a decision-making processes or judgement deviates from norm or rationality (Keren \& Teigen, 2004). Contextual influences and bias affect not only so-called "soft" evidence such as forensic mental health assessments (Neal \& Grisso, 2014) and witness statements (Ask \& Granhag, 2005, 2007), but also "hard" evidence such as fingerprints (Dror, Charlton, \& Péron, 2006; Smalarz, Madon, Yang, Guyll, \& Buck, 2016) and DNA traces (Ask, Rebelius, \& Granhag, 2008).

Furthermore, it now becomes clear that not all types of forensic evidence are equal in terms of reliability and accuracy (Saks \& Koehler, 2005). In fact, some evidence can depreciate the evidentiary weight of subsequently presented evidence. Confessions constitute a prime example (Hasel \& Kassin, 2009; Kassin, Bogart, \& Kerner, 2012). Also in court, different types of evidence are assigned different weights, depending on early influences and occasionally premature interpretations. For example, visceral reactions related to trivial changes such as the presence of a colored or black and white crime photograph can influence jurors' guilty verdicts (Douglas, Lyon, \& Ogloff, 1997). Likewise, judges' rulings in repeated sequential decisions tend to favor the status quo as time progresses (Danziger, Levav, \& Avnaim-Pesso, 2011) and often fail to consider all relevant evidence (Dhami, 2003; Dhami, Belton, \& Goodman-Delahunty, 2015; von Helversen \& Rieskamp, 2009). Moreover, courts often overvalue the quality of evidence (Kovera, \& McAuliff, 2000; Lieberman, Carrell, Miethe, \& Krauss, 2008). For example, mock jurors have been shown to favor a video confession over fingerprint evidence (Schweitzer \& Nuñez, 2018), despite the lack of evidence showing that confessions are more probative than fingerprint matches.

All in all, it has become clear that the information gathering process during the criminal investigation has a direct impact on the nature and quality of the evidence that is presented to prosecutors and judges. In last consequence, that means that the challenges and failures surrounding the collection and interpretation of evidence can shape the future of defendants and change the lives of those who come in contact with the legal system.

This topical issue addresses the challenges relating to the evaluation and application of forensic evidence in criminal proceedings. It aspires to shed light on the role and the corruptive influences of different pieces of evidence, and their interplay in criminal proceedings. Therefore, the articles of this issue fall into three categories:

(a) the evidentiary weight of different types of evidence,

(b) the interaction of different forms of evidence, and

(c) cognitive and behavioral changes that the knowledge of and beliefs about such evidence might generate.

The issue of evidentiary weight of different types of evidence is addressed in four papers. The special issue opens with a review article that identifies 20 threats to the validity of forensic source conclusions. In this article, Koehler 
(2020) illustrates the current state of affairs in evidence evaluation and cautions against the threats that stem from suboptimal procedures and assessors' cognitive confines. Thereby, this review paper stimulates us to think about ways to confront those threats and mitigate their negative consequences.

The next two articles address the issue of contextual influences on the assessment of evidence. QuigleyMcBride's (2020) contribution represents a hands-on approach to the problem of contextual bias in forensic evidence analysis. The article puts forward the use of evidence lineups to protect fingerprint experts from contextual information. In two experiments, novice fingerprint evaluators used the filler-control procedure (i.e., six fingerprints to compare to the crime sample) for matching fingerprints. Compared to the standard procedure (i.e., comparing a single print to a crime print), the filler-control procedure successfully reduced false alarms, even when the fingerprints were too ambiguous to reach a conclusion. The latter is important because ambiguity is known to increase reliance on biased and heuristic thinking (e.g., Ask, Rebelius, \& Granhag, 2008; Neth \& Gigerenzer, 2015).

Sauerland, Otgaar, Maegherman, and Sagana (2020) discuss the role of the expert witness in court and highlight the dangers that lie within the practice of appointing experts by the defense and the prosecution. In a series of three experiments, Sauerland et al. exposed the ease with which bias can be induced and the difficulties with its elimination. Specifically, participants were appointed as expert witness either from the defense or from the prosecution and received an appointment letter that emphasized the arguments of the retaining party. This simple manipulation was sufficient to steer participants' case evaluations to adhere with the party that retained them, namely to induce allegiance bias. Eliminating the bias, however, proved difficult. Neither two-sided instructions nor pre-constructed alternative scenarios were effective.

The last article in this category touches upon the ability of attorneys to recognize when bias has tainted the interpretation of forensic evidence. Attorneys are expected to identify risks that could jeopardise their clients' interests, but their role in detecting forensic bias has largely been neglected in today's literature. Despodova, Kukucka, and Hiley (2020) took on this understudied topic by assessing whether defense attorneys can detect if an autopsy report from a medical examiner had been tainted by knowledge of the defendant's recanted confession. Defense attorneys appeared insensitive to the possibility of biased forensic reporting. In light of these findings, the authors call for procedural reforms to assist the efforts in reducing forensic confirmation bias.

The next group of articles adds to the ongoing discussion about interdependencies in the evaluation of forensic evidence. Two papers are devoted to this topic. Tersago, Vanderhallen, Rozie, and McIntyre (2020) analyzed criminal case files and conducted semi-structured interviews with criminal judges to explore how judges determine the admissibility and validity of a suspect's statement (confession vs. denial) in burglary cases. Specifically, they assessed the extent to which judges (a) took into account the process through which a statement was obtained when judging its value and (b) determined the probative value of the suspect's statement through a comparison with other evidence. In line with earlier work, the findings support the pervasive influence of confessions. How a confession was obtained was not essential for judges' evidence evaluation. Rather, confessions indiscriminately led to convictions, even when the confession was inconsistent with other pieces of evidence and even though judges reported doubting the credibility of confessions in interviews.

Sanson, Crozier, and Strange (2020) show how contextual influences and other evidence, even when nonprobative, impact the assessment of scientific claims. Their contribution examined the courtroom as a contextual factor in judging the accuracy of forensic science claims. Indeed, the courtroom setting - as well as source expertise - increased the perceived credibility of forensic science claims. The credibility of the claims further increased in the presence of non-probative photos. Because the courtroom is a constant contextual influence in civil and criminal cases, Sanson et al. emphasize the need for safeguards in the justice system to ensure that forensic claims made in court are true.

The last category of articles deals with the cognitive and behavioral changes that the knowledge of and beliefs about evidence might generate. The article of Jang, Luke, Granhag, and Vrij (2020) deals with the early steps of the criminal investigation. Jang et al. examined how type of evidence influenced police investigators' beliefs about the reliability of incriminating evidence and the likelihood of the suspect to be the perpetrator. The findings speak to the issue of the perceived reliability of forensic evidence and go a step further in showing that such beliefs can have a direct and immediate impact on investigators' presumption of innocence.

Goodman-Delahunty and Martschuk (2020) examined how admissible incriminating evidence of uncharged prior transgressions can influence jurors' perceptions of criminal intent (mens rea) and report findings of a large experimental jury simulation project. Although prejudicial evidence increased the perception of criminal intent, this evidence did not lead juries to lower their threshold of proof or to engage in impermissible reasoning. This is in contrast to the popular belief that admissible incriminating evidence of uncharged acts is unfairly prejudicial, leading the authors to conclude that the risk of undue prejudice from evidence of prior sexual misconduct might be exaggerated. 
The issue closes with an opinion paper addressing the disconnect between the empirical work in legal decisionmaking and the current legal practice. Specifically, Sagana and van Toor (2020) argue that this disconnect stems from the limited consideration of procedural rules in empirical studies. This in turn increases the skepticism of legal scholars and practitioners of this research and serves as an excuse for dismissing empirical evidence. The paper takes a broader approach to bias in legal decision-making and reflects on issues in the assessment of forensic evidence. The authors close with a call for a collaborative approach between (legal) decision-making researchers and legal scholars in the form of empirical legal studies.

\section{Concluding Remarks}

This special issue reaches out to researchers and practitioners alike and aspires to generate a dialogue between all players involved in the investigation and evaluation of forensic evidence, including forensic experts, attorneys, jurors, and judges. Indeed, most of the studies in this special issue highlight the need for maximizing safeguards and the importance of proper training among forensic experts and legal practitioners. This can best be accomplished when representatives from different disciplines and professions, law and psychology, research and practice, form allegiances.

\section{References}

Ask, K., \& Granhag, P. A. (2005). Motivational sources of confirmation bias in criminal investigations: The need for cognitive closure. Journal of Investigative Psychology and Offender Profiling, 2, 43-63. https://doi.org/10.1002/jip.19

Ask, K., \& Granhag, P. A. (2007). Motivational bias in criminal investigators' judgments of witness reliability. Journal of Applied Social Psychology, 37, 561-591. https://doi.org/ 10.1111/j.1559-1816.2007.00175.x

Ask, K., Rebelius, A., \& Granhag, P. A. (2008). The "elasticity" of criminal evidence: A moderator of investigator bias. Applied Cognitive Psychology, 22, 1245-1259. https://doi.org/10.1002/ acp.1432

Danziger, S., Levav, J., \& Avnaim-Pesso, L. (2011). Extraneous factors in judicial decisions. Proceedings of the National Academy of Sciences, 108, 6889-6892. https://doi.org/10.1073/pnas. 1018033108

Despodova, N. M., Kukucka, J., \& Hiley, A. (2020). Can defense attorneys detect forensic confirmation bias? Effects on evidentiary judgments and trial strategies. Zeitschrift für Psychologie, 228, 216-220. https://doi.org/10.1027/2151-2604/a000414

Dhami, M. K. (2003). Psychological models of professional decision making. Psychological Science, 14, 175-180. https:// doi.org/10.1111/1467-9280.01438
Dhami, M. K., Belton, I., \& Goodman-Delahunty, J. (2015). Quasirational models of sentencing. Journal of Applied Research in Memory and Cognition, 4, 239-247. https://doi.org/10.1016/ j.jarmac.2014.07.009

Douglas, K. S., Lyon, D. R., \& Ogloff, J. R. (1997). The impact of graphic photographic evidence on mock jurors' decisions in a murder trial: Probative or prejudicial?. Law and Human Behavior, 21, 485-501. https://doi.org/10.1023/A:1024823706560

Dror, I. E., Charlton, D., \& Péron, A. E. (2006). Contextual information renders experts vulnerable to making erroneous identifications. Forensic Science International, 156, 74-78. https://doi.org/10.1016/j.forsciint.2005.10.017

Dror, I., \& Rosenthal, R. (2008). Meta-analytically quantifying the reliability and biasability of forensic experts. Journal of Forensic Sciences, 53, 900-903. https://doi.org/10.1111/j.1556-4029. 2008.00762.x

Goodman-Delahunty, J., \& Martschuk, N. (2020). Mock jury and juror responses to uncharged acts of sexual misconduct: Advances in the assessment of unfair prejudice. Zeitschrift für Psychologie, 228, 199-209. https://doi.org/10.1027/2151-2604/ a000410

Hasel, L. E., \& Kassin, S. M. (2009). On the presumption of evidentiary independence: Can confessions corrupt eyewitness identifications?. Psychological Science, 20, 122-126. https://doi.org/10.1111/j.1467-9280.2008.02262.x

Jang, M., Luke, T. J., Granhag, P. A., \& Vrij, A. (2020). The impact of evidence type on police investigators' perceptions of suspect culpability and evidence reliability. Zeitschrift für Psychologie, 228, 188-198. https://doi.org/10.1027/2151-2604/a000411

Kassin, S. M., Bogart, D., \& Kerner, J. (2012). Confessions that corrupt: Evidence from the DNA exoneration case files. Psychological Science, 23, 41-45. https://doi.org/10.1177/ 0956797611422918

Kassin, S. M., Dror, I. E., \& Kukucka, J. (2013). The forensic confirmation bias: Problems, perspectives, and proposed solutions. Journal of Applied Research in Memory and Cognition, 2, 42-52. https://doi.org/10.1016/j.jarmac.2013.01.001

Keren, G., \& Teigen, K. H. (2004). Yet another look at the heuristics and biases approach. In Derek J. Koehler \& Nigel Harvey (Eds.), Blackwell handbook of judgment and decision making (pp. 89109). Oxford, UK: Blackwell Publishing Ltd.

Kiely, T. F. (2005). Forensic evidence: Science and the criminal law. CRC Press.

Killgrove, K. (2018). These three forensic science techniques from ancient Rome reveal shocking gaps in modern methods. Forbes. Retrieved from https://www.forbes.com/sites/kristinakillgrove/ 2018/11/28/these-three-forensic-science-techniques-fromancient-rome-reveal-shocking-gaps-in-modern-methods/ \#76722a9a58fe

Koehler, J. J. (2020). Forensic source conclusions: Twenty threats to validity. Zeitschrift für Psychologie, 228, 149-161. https:// doi.org/10.1027/2151-2604/a000413

Kovera, M. B., \& McAuliff, B. D. (2000). The effects of peer review and evidence quality on judge evaluations of psychological science: Are judges effective gatekeepers?. Journal of Applied Psychology, 85, 574. https://doi.og/10.1037/0021-9010.85.4.574

Lieberman, J. D., Carrell, C. A., Miethe, T. D., \& Krauss, D. A. (2008). Gold versus platinum: Do jurors recognize the superiority and limitations of DNA evidence compared to other types of forensic evidence? Psychology, Public Policy, and Law, 14, 27-62. https://doi.org/10.1037/1076-8971.14.1.27

Neal, T., \& Grisso, T. (2014). The cognitive underpinnings of bias in forensic mental health evaluations. Psychology, Public Policy, and Law, 20, 200-211. https://doi.org/10.1037/a0035824

Neth, H., \& Gigerenzer, G. (2015). Heuristics: Tools for an uncertain world. In R. Scott \& S. Kosslyn (Eds.), Emerging 
trends in the social and behavioral sciences: An interdisciplinary, searchable, and linkable resource.. New York, NY: Wiley Online Library1-18.

Quigley-McBride, A. (2020). Practical solutions to forensic contextual bias. Zeitschrift für Psychologie, 228, 162-174. https:// doi.org/10.1027/2151-2604/a000409

Sagana, A., \& van Toor, D.A.G. (2020). The judge as a procedural decision-maker: Addressing the disconnect between legal psychology and legal practice. Zeitschrift für Psychologie, 228, 226-228. https://doi.org/10.1027/2151-2604/a000417

Saks, M. J., \& Koehler, J. J. (2005). The coming paradigm shift in forensic identification science. Science, 309, 892-895. https:// doi.org/10.1126/science.1111565

Sanson, M., Crozier, W. E., \& Strange, D. (2020). Court case context and fluency-promoting photos inflate the credibility of forensic science. Zeitschrift für Psychologie, 228, 221-225. https://doi.org/10.1027/2151-2604/a000415

Sauerland, M., Otgaar, H., Maegherman, E., \& Sagana, A. (2020). Allegiance bias in statement reliability evaluations is not eliminated by two-sided instructions. Zeitschrift für Psychologie, 228, 210-215. https://doi.org/10.1027/2151-2604/ a000416

Schweitzer, K., \& Nuñez, N. (2018). What evidence matters to jurors? The prevalence and importance of different homicide trial evidence to mock jurors. Psychiatry, Psychology, and Law, 25, 437-451. https://doi.org/10.1080/13218719.2018.1437666
Smalarz, L., Madon, S., Yang, Y., Guyll, M., \& Buck, S. (2016). The perfect match: Do criminal stereotypes bias forensic evidence analysis? Law and Human Behavior, 40, 420-429. https://doi. org/10.1037/Lhb0000190

Tersago, P., Vanderhallen, M., Rozie, J., \& Mclntyre, S. J. (2020). From suspect statement to legal decision making: How do judges weigh the evidence? Zeitschrift für Psychologie, 228, 175-187. https://doi.org/10.1027/2151-2604/a000412

von Helversen, B., \& Rieskamp, J. (2009). Predicting sentencing for low level crimes: Comparing models of human judgment. Journal of Experimental Psychology: Applied, 15, 375-395. https://doi. org/10.1037/a0018024

\section{History}

Published online XXX, 2020

\section{Anna Sagana}

Section Forensic Psychology

Faculty of Psychology and Neuroscience

Maastricht University

PO Box 616

6200 MD Maastricht

The Netherlands

anna.sagana@maastrichtuniversity.nl 